\title{
First records of the powdery mildews Erysiphe platani and $E$. alphitoides on Ailanthus altissima reveal host jumps independent of host phylogeny
}

\author{
L. Beenken ${ }^{1}$
}

Received: 10 November 2016 /Revised: 11 December 2016 / Accepted: 13 December 2016/Published online: 6 January 2017

(C) German Mycological Society and Springer-Verlag Berlin Heidelberg 2017

\begin{abstract}
The tree-of-heaven Ailanthus altissima (family Simaroubaceae, order Sapindales) is one of the most invasive neophytes in Europe. The tree originated in China and became invasive worldwide in areas with Mediterranean to temperate climates. As known from other invasive plants, only a few pathogens have been reported from A. altissima in Europe, and, to date, powdery mildews on it have been unknown in the European region. Recently, two powdery mildews were found on A. altissima during a survey of neomycetes on non-native plants in Switzerland. Because they did not fit with any of the species known to occur on Simaroubaceae in Asia, they were identified by DNA barcoding using sequences of the ITS region of the n-rDNA, revealing them to be the powdery mildews of plane and oak trees, Erysiphe platani and E. alphitoides. This is the first record of E. platani on a host outside the genus Platanus and its family Platanaceae, as well as its order Proteales. In contrast, E. alphitoides has been reported to occur on several host families and orders. Host jumps over great phylogenetic distances - such as across plant families and orders - appear to be quite common in biogeographically novel associations between Erysiphales species and plants. The consequences of such host jumps for identity and taxonomic placement of species are discussed here. It is further questioned whether both pathogens are usable as biological control agents against the tree-of-heaven.
\end{abstract}

Section Editor: Dominik Begerow

Electronic supplementary material The online version of this article (doi:10.1007/s11557-016-1260-2) contains supplementary material, which is available to authorized users.

L. Beenken

ludwig.beenken@wsl.ch

1 Swiss Federal Research Institute WSL, CH-8903 Birmensdorf, Switzerland
Keywords Biological control · DNA barcoding · Erysiphales $\cdot$ Host range $\cdot$ Neomycetes $\cdot$ Neophytes

\section{Introduction}

Non-native fungi, so-called neomycetes (Kreisel and Scholler 1994), are the least well-investigated group of neobiota even though they have the potential to harm indigenous flora and fauna. Many neomycetes are associated with similarly introduced plants, from which they can potentially spill over onto indigenous plants (Beenken and Senn-Irlet 2016). In response to this phenomenon, neophytes in particular were checked for fungal infections during a survey of neomycetes on plants in Switzerland, with the aim, among others, to find fungal species potentially suitable for biological control against invasive plants (Beenken and Senn-Irlet 2016). This survey included the tree-of-heaven Ailanthus altissima (Mill.) Swingle (Simaroubaceae, Sapindales), which is one of the most common invasive neophytes in Europe. It is native to China and was introduced to Europe and North America in the 1740s where it was often planted as an ornamental urban tree. Later, it became invasive worldwide in areas with Mediterranean to temperate climates (Kowarik and Säumel 2007). In Switzerland, the tree-of-heaven is distributed mainly in the southern areas but also in urban regions north of the Alps. It is also spreading in forest habitats potentially favored by climate warming (Gurtner et al. 2015). In addition to its negative effect on native ecosystems in general (Kowarik and Säumel 2007), the expansion of the tree-of-heaven in mountain forests can reduce their protecting function for humans and infrastructures against rock fall (Knüsel et al. 2015). Ailanthus altissima is, therefore, on the "black list" of invasive neophytes in Switzerland (Weber 2013, infoflora.ch). 
Alien plant species can become invasive in a new area when they are released from their natural pathogens and predators in a new environment, resulting in a fitness advantage over native species according to the widely accepted enemyrelease hypothesis (e.g., Mitchell and Power 2003; for a contrasting position, see van Kleunen and Fischer 2009). Thus, programs against invasive plants often use specific pathogens from their native range for biological control (e.g., Hajek 2004, Tanner et al. 2015).

Only a few fungi are known to occur on the tree-of-heaven in Europe. While most are unspecific common wood-decaying fungi, some leaf diseases caused by Verrticillium spp. and Cercospora spp. have been reported (Kowarik and Säumel 2007; Siegrist and Holdenrieder 2016). Powdery mildews (Erysiphales, Ascomycota) occurring on Ailanthus or other Simaroubaceae have been almost unknown in Europe, where Simaroubaceae are not indigenous (Braun and Cook 2012; Farr and Rossman 2016). To date, the only such case comes from Klenke and Scholler (2015) who reported a conidial stage of an unidentified Podosphaera species on Ailanthus in Germany. Braun and Cook (2012) listed four species on Ailanthus in Asia: Erysiphe delavayi (Pat.) U. Braun \& Takam, E. picrasmicola U. Braun \& S. Takam. (both Erysiphe sect. Uncinula), Phyllactinia ailanthi (Golovin \& Bunkina) Y.N. $\mathrm{Yu}$, and Pseudoidium ailanthi (Bhagyan. \&Ramachar) U. Braun \& R.T.A. Cook. Additionally, E. picrasmae (Sawada) U. Braun \& S. Takam. (E. sect. Microsphaera) has been reported on Picrasma, another genus of Simaroubaceae.

Given the rarity of such powdery mildews, it was unexpected for them to be found on several young trees of A. altissima in the cities of Basel and Zurich. However, these Swiss collections could not be assigned to one of the known powdery mildews of Ailanthus or other Simaroubaceae following Braun and Cook (2012). Thus, the question arose whether new fungal species had been discovered or whether already known powdery mildews infected the tree-of-heaven via host jumps from other plants outside of Simaroubaceae.

\section{Materials and methods}

Morphological analyses Fungal structures were investigated from fresh material in water by light microscopy with $\times 100$, $\times 400$ and $\times 1000$ magnification. Some $10-20$ conidia, 5-10 conidiophores and (where present) 5-10 ascomata, so-called chasmothecia, of each collection were measured to determine their size range (following Braun and Cook 2012). For microphotographs and drawings, conidia, conidiophores and chasmothecia were prepared from dried material and mounted in lactic acid using a fine needle (see Beenken et al. 2012).

Molecular analyses Small pieces of leaves $(\sim 5 \times 5 \mathrm{~mm})$ with fungal infections were dried on silica gel. Total DNA was extracted from chasmothecia (samples LB10424, LB10725, LB10733) or conidiophores (sample LB10721) scraped off the dried material using NucleoSpin Plant II extraction kits (Macherey-Nagel, Düren, Germany) following the manufacturer's standard protocol for plant tissue. The ITS1-5.8S-ITS2 region of n-rDNA (DNA barcode for fungi; see Schoch et al. 2012) was PCR-amplified and sequenced (following the protocol in Beenken et al. 2012) using the primer ITS1F and ITS4 (Gardes and Bruns 1993; White et al. 1990). Sequences were deposited in GenBank (accession numbers in Table S1 and Fig. 1).

For species identification, ITS sequences were compared with accessions deposited in GenBank by applying the Basic Local Alignment Search Tool (BLAST) using the nucleotide search option (BLASTn) (Altschul et al. 1990).

The alignment of 132 ITS sequences was based on the part of the ITS dataset in Takamatsu et al. (2015) around their "E. alphitoides", "E. quercicola" and "E. platani" clades that was complemented with further sequences including the four ITS sequences from Ailanthus powdery mildews (Table S1). Alignment was performed using MAFFT v.7.017 (Katoh et al. 2002). There were no ambiguous regions within the resulting alignment that required exclusion from the analysis.

The dataset underwent maximum likelihood-based phylogenetic analysis implemented in RAxML v.7.2.8 (Stamatakis 2006). The analysis assumed a general time-reversible (GTR) model of nucleotide substitution and estimated a discrete gamma distribution (GTRGAMMA option in RAxML) with partitions according to the sub-matrices (ITS1/5,8S/ITS2/LSU), which allowed multiple models of substitution. One thousand runs with distinct starting trees were completed using the rapid bootstrap (BS) algorithm of RAxML (Stamatakis et al. 2008). The resulting phylogenetic ML tree (Fig. 1) was rooted on E. paeoniae R.Y. Zheng \& G.Q. Chen (cf. Takamatsu et al. 2015) and visualized using the Dendroscope program (Huson et al. 2007).

\section{Results}

Two morphologically different powdery mildews occurred on A. altissima in Switzerland that were identified using DNA barcoding as follows.

The three samples LB10424, LB10725 and LB10733 bearing chasmothecia and long conidiophores revealed identical ITS sequences. A BLASTn search of these nucleotides showed 100\% matches with sequences from Erysiphe platani on Platanus $\times$ acerifolia from Germany (GenBank no. JQ365940, JQ365942) and Italy (JQ365941). They form, together with all $E$. platani sequences, a well-supported clade in the phylogenetic analysis (Fig. 1).

One sample on A. altissima (LB10721) had only a conidial stage. Its sequence was $100 \%$ identical to sequences from 
Fig. 1 Positions of the powdery mildews on Ailanthus altissima within the phylogenetic tree of Microsphaera lineages of the genus Erysiphe (red arrowheads). Maximum-likelihood analysis with RAxML v.7.2.6 recovered from ITS sequence data. Numbers at nodes indicate RAxML bootstrap support $>50 \%$. Samples are given with host plant,

GenBank accession number and origin (cf. Table S1)

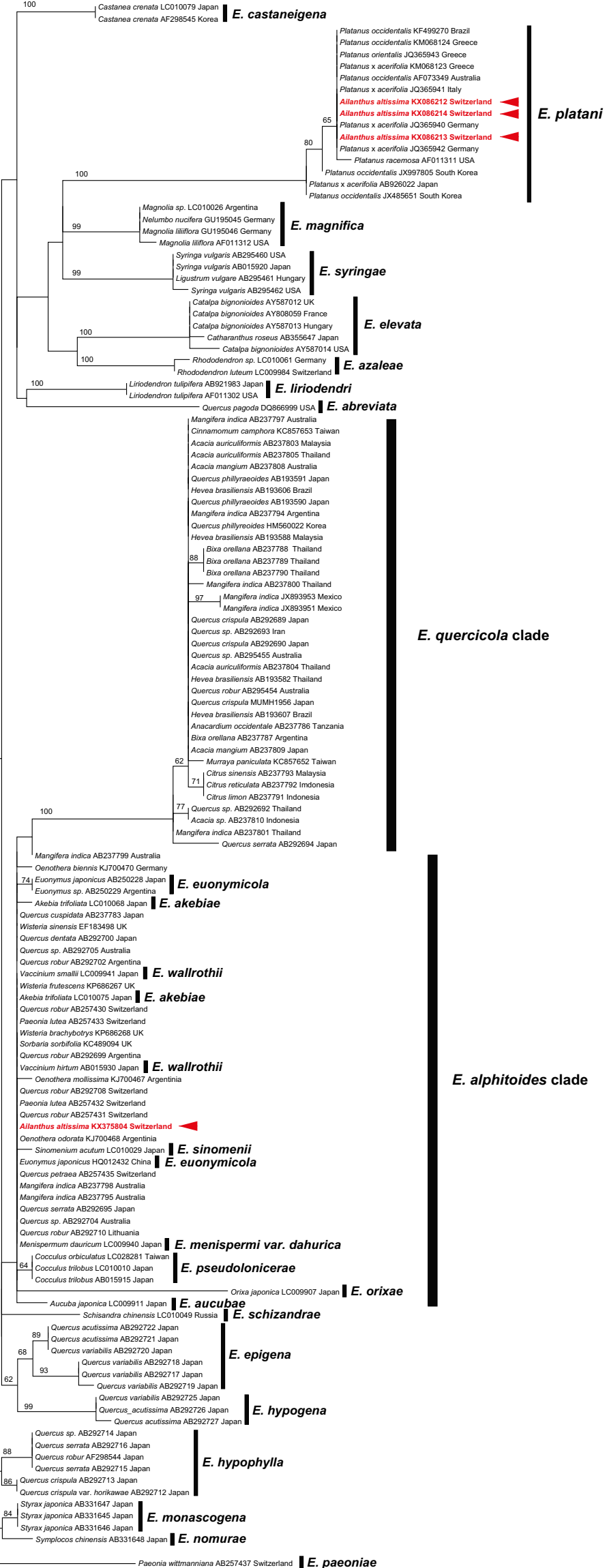


E. alphitoides on Quercus spp. in GenBank (e.g., AB292699AB292705), on Wisteria spp. (e.g., KP686267-KP686269), on Oenothera (KJ700468), on Paeonia (AB257434), on Mangifera (AB237795) and on Sorbaria (KC489094). However, it is also $100 \%$ identical to E. akebiae (Sawada) U. Braun \& S. Takam. on Akebia spp. (LC010075) and E. wallrothii (U. Braun \& Tanda) U. Braun \& S. Takam. on Vaccinium spp. (AB015930, LC010088). All these samples appear within the E. alphitoides clade of the phylogeny (Fig. 1; Table S1).

The morphological characteristics confirmed the molecular results and the identification of the powdery mildews on Ailanthus as E. platani and E. alphitoides since they match their descriptions found in Braun and Cook (2012).

Erysiphe platani (Howe) U. Braun \& S. Takam. on Ailanthus altissima

$\equiv$ Microsphaera platani Howe

(Figs. 2 and 3a)

The mycelium on leaflets hypopyllous or rarely amphigenous, forming dense, white patches of c. $0.5-2 \mathrm{~cm}$ in diameter; leaflets often deformed and slightly contorted (as on Platanus); hyphae about 4-8 $\mu \mathrm{m}$ wide, hyphal appressoria lobed; conidiophores erect, 1-4(5) septate, up to $240 \mu \mathrm{m}$ long, 5-9 $\mu \mathrm{m}$ wide, foot-cells straight, 30-95 $\times 4-7 \mu \mathrm{m}$; conidia doliiform, $30-45 \times 15-20 \mu \mathrm{m}$; chasmothecia scattered, 100
$120(135) \mu \mathrm{m}$ in diam.; appendages $6-12,1-2$ times as long as the chasmothecia in diameter, $6-10 \mu \mathrm{m}$ wide, $0-1$ septum close to the base, hyaline, brown at the base, apices 4-5 times dichotomously branched, with curved tips; asci 3-6, obovoid, 40-70 $\times 30-55 \mu \mathrm{m}$, wall $2 \mu \mathrm{m}$ thick, 3-5 spored; ascospores $20-25 \times 12-17 \mu \mathrm{m}$.

Vouchers (in ZT): Switzerland, Basel, 47'33'49”N, 7³5’05"E, alt. 250 m, 12 Nov 2015, leg. L. Beenken/ 10725, GenBank no. KX086213; Basel, 47³5'52”N, 7³5'10”'E, alt. 250 m, 12 Nov 2015, leg. L. Beenken/ 10733, GenBank no. KX086214; Zurich, 47²2’09”N, $8^{\circ} 30^{\prime} 21$ ”'E, alt. 430 m, 13 Oct 2015, leg. L. Beenken/10424, GenBank no. KX086212.

Erysiphe alphitoides (Griff. \& Maubl.) U. Braun \& S. Takam. on Ailanthus altissima

$\equiv$ Microsphaera alphitoides Griff. \& Maubl.

(Fig. 3b)

Mycelium on leaflets mainly hypopyllous or rarely amphigenous, forming small, white patches of c. $0.5-1 \mathrm{~cm}$ in diameter; leaflets never deformed; hyphae about 4-8 $\mu \mathrm{m}$ wide, hyphal appressoria lobed; conidiophores erect, 1-2 septate, up to $40 \mu \mathrm{m}$ long, 5-7 $\mu \mathrm{m}$ wide, foot-cells straight, 15 $30 \times 5-8 \mu \mathrm{m}$; conidia cylindrical to doliiform, 25-35 × 10-15 $\mu \mathrm{m}$; chasmothecia lacking.
Fig. 2 a Erysiphe platani on Ailanthus altissima. b Infected leaf with deformations caused by the fungal mycelium. c Chasmothecium
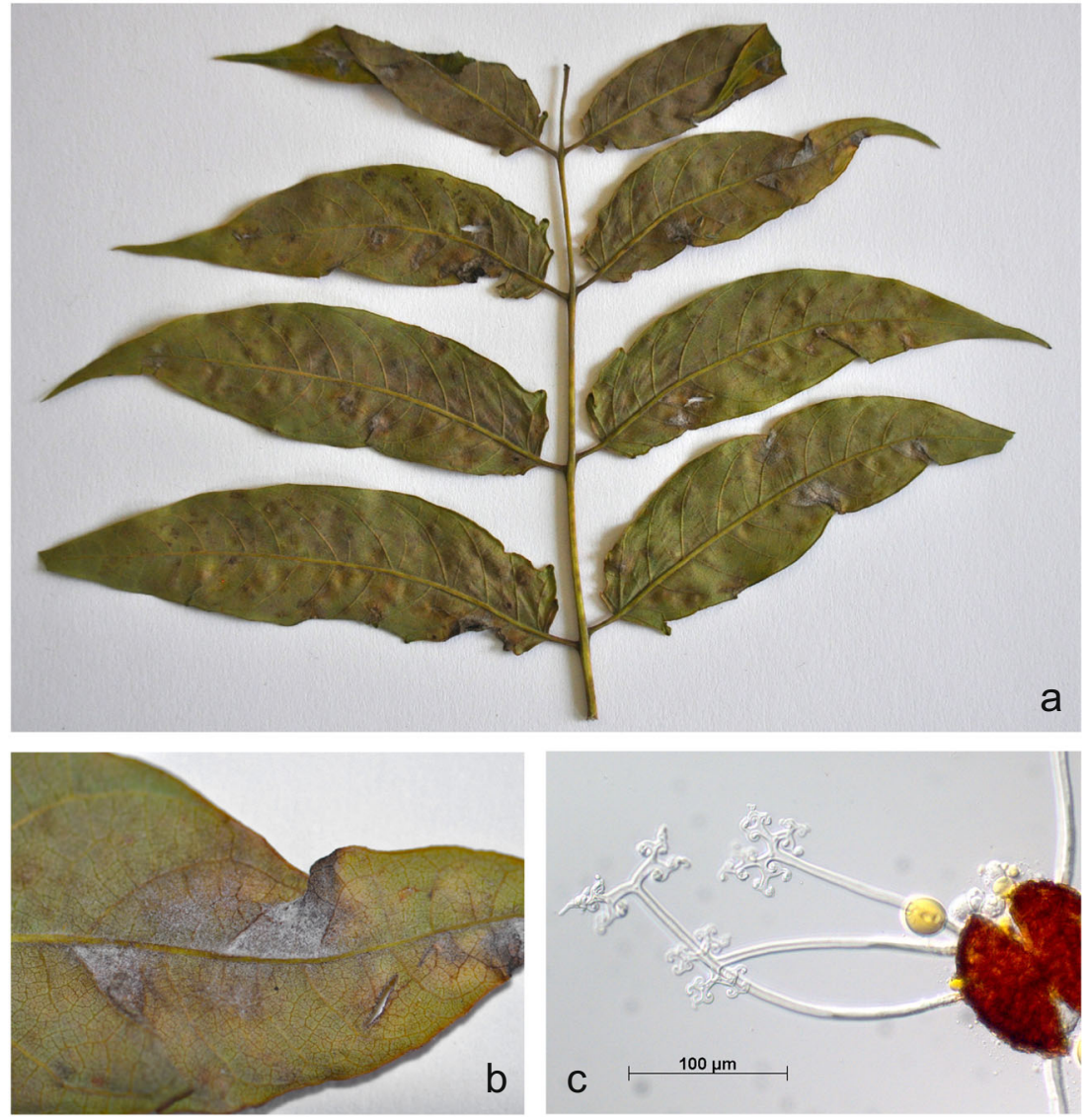

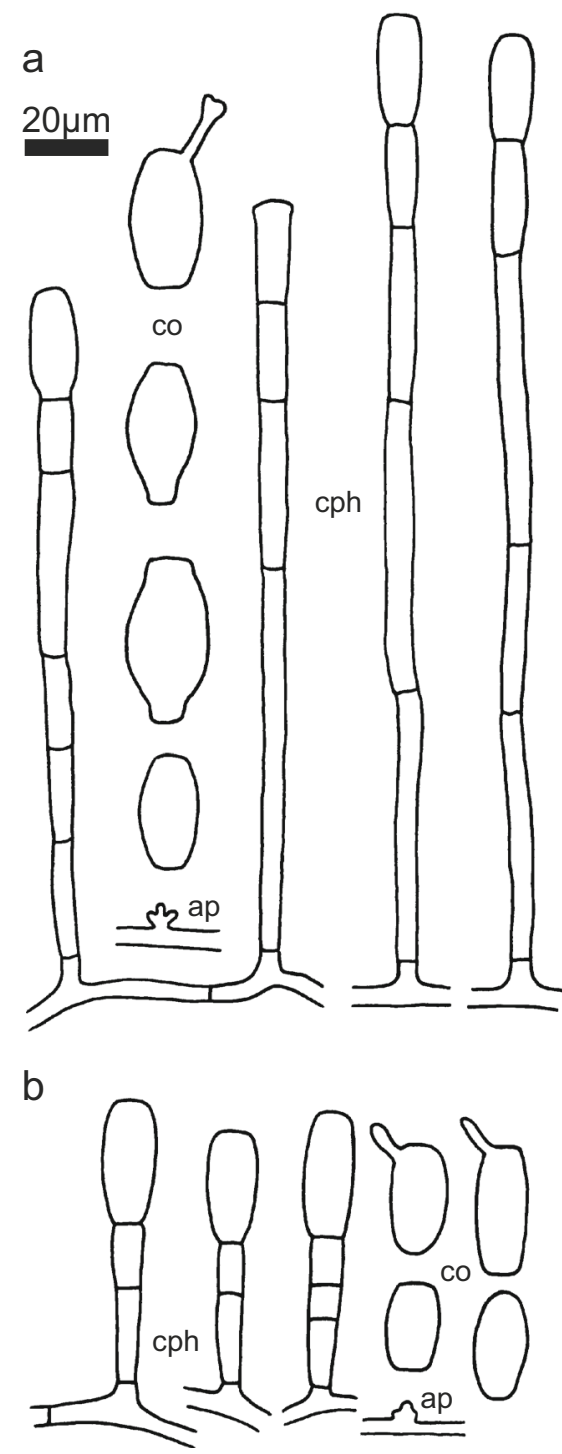

Fig. 3 Pseudoidium on Ailanthus altissima: a Erysiphe platani; b Erysiphe alphitoides. ap hyphal appressoria, co conidia, $c p h$ conidiophores

Voucher (in ZT): Switzerland, Basel, 47 $33^{\prime} 30^{\prime \prime} \mathrm{N}, 7^{\circ} 34^{\prime}$ 52"E, alt. 270 m, 12 Nov 2015, leg. L. Beenken/10721, GenBank no. KX375804

\section{Discussion}

\section{Species identity}

Both Erysiphe species found on Ailanthus belong to Erysiphe sect. Microsphaera and are neomycetes introduced to Europe (Braun and Cook 2012). E. platani originates from North America and is a globally distributed neomycete on Platanus spp. (Pastirčáková et al. 2014). First records in Europe came from southern Italy in the early twentieth century (Sprenger 1916). From there it reached Ticino in
Switzerland south of the Alps in 1988 (Bolay 2005). Nowadays, it is also common and widely distributed north of the Alps where plane trees are planted (Bolay 2005; Scholler et al. 2012; see current distribution in Switzerland in Senn-Irlet et al. 2016). The presented observations on A. altissima are the first records of $E$. platani on a host outside the genus Platanus. Plane trees heavily infected by E. platani were observed in close vicinity to the infected trees-of-heaven in Zurich and Basel. This likely caused high infection pressure and resulted in a short infection path from the ordinary, natural host to the new host plant. A conspicuous symptom on both hosts was the characteristic deformation of the infected leaves (Fig. 2a, b; Kirschner 2011). The length (up to $200 \mu \mathrm{m}$ ) of the conidiophores (Fig. 3a) was an additional feature of this species that differentiated it from other members of $E$. sect. Microsphaera (Braun and Cook 2012).

In contrast, the second powdery mildew on Ailanthus did not deform the leaves and had shorter (up to $40 \mu \mathrm{m}$ ) conidiophores (Fig. 3b), a rather common feature in the genus Erysiphe. DNA sequencing was, therefore, indispensable for its unequivocal identification as E. alphitoides. The origin and natural hosts of $E$. alphitoides are unknown. It suddenly appeared in western Europe at the end of the nineteenth century on oaks (Mougou et al. 2008). In Switzerland, Mayor (1908) initially reported it as Microsphaera alni on $Q$. pendunculata $(=Q$. robur) collected in 1899 in Geneva (Beenken and SennIrlet 2016). At present, E. alphitoides has a worldwide distribution mainly on Quercus spp. and on other genera of the family Fagaceae. It is, however, also reported on many hosts unrelated to the Fagaceae (Braun and Cook 2012; Takamatsu et al. 2015; Table S1). Although Gadgil (2005) listed A. altissima as a host of E. alphitoides in New Zealand, ascomata were not found, and its identity was not proven by DNA sequencing. E. picrasmae was the only other member of E. sect. Microsphaera occurring on Simaroubaceae (Braun and Cook 2012). It has been reported on Picrasma quassioides from Japan, China and Korea and has very similar morphological charteristics compared to E. alphitoides (Braun and Cook 2012). DNA sequence data of this species is still lacking to evaluate its phylogenetic position and especially its relationship to E. alphitoides.

\section{Host jumps}

It is generally assumed that host jumps of plant pathogenic fungi occur mainly between closely related plant species (Bufford et al. 2016; Gilbert and Webb 2007; Gilbert et al. 2012). In contrast to this assumption, host jumps between plants of greater phylogenetic distance have been reported in powdery mildews several times (e.g., Cook et al. 2015; Kirschner 2010; Limkaisang et al. 2005, 2006; Watanabe and Sato 2009). These observed host jumps of E. platani and E. alphitoides have occurred across taxonomic boundaries 
between hosts of different plant families and even orders, spilling over from Platanaceae (order Proteales) and from Fagaceae (order Fagales) to Simaroubaceae (order Sapindales), respectively. It is worth noting that E. platani and E. alphitoides, as well as both the host plants involved, Platanus and Ailanthus, are not native to Switzerland where the host jumps occurred.

In similar fashion, Kirschner (2010) reported an unusually long host jump by the North American E. magnifica (Sawada) U. Braun \& S. Takam. from Magnolia (Magnoliaceae, Magnoliales) onto the Indian lotus Nelumbo nucifera (Nelumbaceae, Proteales) in Germany. In Japan, Watanabe and Sato (2009) found the North American E. elevata (Burrill) U. Braun \& S. Takam, the powdery mildew of Catalpa (Bignoniaceae, Lamiales), on Catharantus roseus (Apocynaceae, Gentiales) originating from Madagascar. In both cases, neither the fungi nor the host plants were native to the location where the host jumps occurred.

Interestingly, the two oak mildews, E. alphitoides and the closely related E. quercicola S. Takam. \& U. Braun, are known to infest many plant species of several families and orders all over the world (Fig. 1; Table S1 and references therein; see also Braun and Cook 2012). For example, E. alphitoides could be unambiguously identified by means of sequencing and infection experiments on Wisteria spp. (Fabaceae, Fabales) introduced as an ornamental climber from Asia to the UK (Cook et al. 2015; Denton et al. 2016). The following species also appeared within the E. alphitoides clade, and are morphologically very similar to E. alphitoides: Erysiphe akebiae, E. euonymicola U. Braun, E. menispermi var. dahurica (U. Braun \& Y. Nomura) U. Braun \& S. Takam., E. orixae (U. Braun \& Tanada) U. Braun \& S. Takam., E. pseudolonicerae (E.S. Salmon) U. Braun \& S. Takam., E. sinomenii (Y.N. Yu) U. Braun and E. wallrothii (Fig. 1; Table S1; Takamatsu et al. 2015). It is, therefore, necessary to consider whether they are biologically distinct species or are conspecific with $E$. alphitoides. In the latter case, these species would be erroneously described as new to science based on misinterpretations of the undetected host jumps of $E$. alphitoides onto new plant taxa. However, it must be kept in mind that the sequences of the ITS region cannot always discriminate between biologically wellseparated species (e.g., Beenken et al. 2012; Schoch et al. 2012). The Erysiphe sample on Aucuba japonica also appeared in the E. alphitoides clade (Fig. 1), but was distinguished by its ITS sequence and, consequently, was recently described as E. aucubae S. Takam. \& Siahaan (Siahaan and Takamatsu 2016). Takamatsu et al. (2015) identify further clades in their phylogeny of Erysiphe sect. Microsphaerasuch as the E. aquilegiae clade - that contain closely related mildew species that, while occurring on unrelated host plants, could not be distinguished by their ITS sequences. In contrast, some samples on the same or closely related host plants appear in different places in the phylogeny of Takamatsu et al. (2015). Takamatsu et al. (2008) also found the host range expansion of Phyllactinia spp. to be independent of host plant phylogeny and discussed the implications for taxonomy and biogeography of the genus. Although polyphagous species were already known in other genera of Erysiphales - such as Golovinomyces orontii (Castagne) Heluta-some were revealed to be species complexes of several oligophagous species, such as the Golovinomyces cichoracearum complex (Braun and Cook 2012. Cunnington et al. 2010. Takamatsu et al. 2013).

In conclusion, the host range of Erysiphales appears to be not as strict as assumed in the past, especially when plants and fungi come together from biogeographically different regions and are obviously not adapted to each other. Thus, novel interactions between introduced powdery mildews and plants cannot be predicted by the evolutionary distance of the host species as recommended for phytosanitary risk analyses of biological control agents against invasive neophytes (compare Bufford et al. 2016; Gilbert and Webb 2007; Gilbert et al. 2012).

\section{Biological control of neophytes}

The tree-of-heaven is a dangerous invasive plant that must be eradicated where it invades natural habitats. Chemical control in forest stands is, however, forbidden in some countries, as is the case in Switzerland, and mechanical control entails significant effort and cost (Gurtner et al. 2015; Kowarik and Säumel 2007). Given these considerations, a biological control using pathogenic fungi could be a viable alternative (Ding et al. 2006; Kasson et al. 2014, 2015; Siegrist and Holdenrieder 2016). On the other hand, the intentional release of pathogenic fungi for biocontrol programs could also be harmful to native plants. For this reason, the introduction and release of alien organisms are strongly regulated and limited (Schaffner and Escher 2012). These regulations would not apply to $E$. alphitoides and $E$. platani because they are neomycetes that are already established in Europe (Beenken and Senn-Irlet 2016). However, both powdery mildews harm the leaves of the tree-of-heaven only weakly. The observed infections were small in size and developed late in the year at the end of the growth period. Thus, neither powdery mildew is suitable to control the neophyte. A more effective option is the Verticillium wilt caused by $V$. nonalfalfae Inderb. et al. that kills the tree-of-heaven (Kasson et al. 2014, 2015; Maschek and Halmschlager 2016; Siegrist and Holdenrieder 2016). This strain of $V$. nonalfalfae specific to the tree-of-heaven may be proposed as a biocontrol agent. Currently, it is only known in the USA and some locations in Austria (Kasson et al. 2014, 2015; Maschek and Halmschlager 2016; Siegrist and Holdenrieder 2016). 


\section{Conclusion}

Plants appear to be protected against pathogens that are not adapted to them by a general resistance, the so-called "nonhost" resistance (e.g., Antonovics et al. 2013; Gill et al. 2015; Lipka et al. 2010). In contrast, the present study, as well as the publications cited in it, show that some fungal pathogens of Erysiphales can overcome this non-host resistance of plants unrelated to their original hosts. This is particularly the case if fungi and their novel host plants had not been in contact before they came together from biogeographically different regions. In this way, the plant resistance mechanism obviously could not adapt to these novel non-host pathogens.

In summary, the observations of powdery mildews on novel hosts have the following consequences in plant pathology.

(i) In taxonomy, undetected host jumps could result in wrong identification of species if based more or less only on the host ranges of the pathogenic fungi-which was often the case especially in the time before DNA barcoding. New taxa should be established only after verification by molecular phylogeny.

(ii) In conservation management, the possibility of unexpected host jumps must be taken into account when assessing the risks of introducing particular fungi.

(iii) In molecular plant pathology, more detailed investigation of cross-family and cross-order host jumps could contribute to improved understanding of fungal infection and plant resistance mechanisms.

Acknowledgements The author thanks Beatrice Senn-Irlet (WSL Brimensdorf) for her great support during the study, Andrin Gross (WSL Brimensdorf) for his helpful comments to the manuscript, and Curtis Gautschi (ZHAW Winterthur) for the language revision. Molecular data was produced and analyzed in collaboration with the Genetic Diversity Centre (GDC) of the ETH Zurich. The Swiss Federal Office for the Environment financed this study (FOEN project 05.0040.PZ/O282-2391).

\section{References}

Altschul SF, Gish W, Miller W, Myers EW, Lipman DJ (1990) Basic local alignment search tool. J Mol Biol 215:403-410

Antonovics J, Boots M, Ebert D, Koskella B, Poss M, Sadd BM (2013) The origin of specificity by means of natural selection: evolved and nonhost resistance in host-pathogen interactions. Evolution 67:1-9

Beenken L, Senn-Irlet B (2016) Neomyceten in der Schweiz, Stand des Wissens und Abschätzung des Schadpotentials der mit Pflanzen assoziierten gebietsfremden Pilze. WSL Berichte 50. www.wsl. ch/publikationen/pdf/15783.pdf

Beenken L, Zoller S, Berndt R (2012) Rust fungi on Annonaceae II: the genus Dasyspora Berk. \& M.A. Curtis. Mycologia 104:659-681

Bereczky Z, Pintye A, Csontos P, Braun U, Kiss L (2015) Does the parasite follow its host? Occurrence of morphologically barely distinguishable powdery mildew anamorphs on Oenothera spp. in different parts of the world. Mycoscience 56:267-272. doi:10.1016/j.myc.2014.08.001

Bolay A (2005) Les Oidiums de Suisse (Erysiphacées). Cryptogam Helv 20:1-174

Braun U, Cook RTA (2012) Taxonomic manual of the Erysiphales (powdery mildews), CBS Biodiversity Ser 11. CBS, Utrecht

Braun U, Shi A, Mmbaga M, Takamatsu S, Divarangkoon R, Chen P (2007) Erysiphe abbreviata on cherry bark oak - morphology, phylogeny and taxonomy. Mycologia 99:655-663

Bufford JL, Hulme PE, Sikes BA, Cooper JA, Johnston PR, Duncan RP (2016) Taxonomic similarity, more than contact opportunity, explains novel plant-pathogen associations between native and alien taxa. New Phytol 212:657-667. doi:10.1111/nph.14077

Cheon W, Lee SG, Jeon YH (2014) First report of powdery mildew caused by Erysiphe alphitoides on Japanese snailseed (Cocculus trilobus) in Korea. Plant Dis 98:685. doi:10.1094/PDIS-01-130031-PDN

Cook RTA, Denton JO, Denton G (2015) Pathology of oak - wisteria powdery mildew. Fungal Biol 119:657-671

Cook RTA, Henricot B, Kiss L (2004) First record of Erysiphe elevata on Catalpa bignonioides in the UK. Plant Pathol 53:807

Cunnington JH, Lawrie AC, Pascoe IG (2010) Genetic characterization of the Golovinomyces cichoracearum complex in Australia. Plant Pathol 59:158-164. doi:10.1111/j.1365-3059.2009.02175.x

Cunnington JH, Takamatsu S, Lawrie AC, Pascoe IG (2003) Molecular identification of anamorphic powdery mildew (Erysiphales). Australas Plant Pathol 32:421-428

Denton GJ, Denton JO, Cook RTA (2013) First report of powdery mildew on Sorbaria. New Dis Rep 28:15. doi:10.5197/j.20440588.2013.028.015

Denton GJ, Denton JO, Cook RTA (2016) First record of Erysiphe alphitoides on Wisteria brachybotrys and $W$. frutescens, and first record of its chasmothecia on Wisteria. New Dis Rep 33:5. doi:10.5197/j.2044-0588.2016.033.005

Ding J, Wu Y, Hao Z, Weidong F, Reardon R, Liu M (2006) Assessing potential biological control of the invasive plant, tree-of-heaven, Ailanthus altissima. Biocontrol Sci Technol 16:547-566

Farr DF, Rossman AY (2016) Fungal Databases, Systematic Mycology and Microbiology Laboratory, ARS, USDA. http://nt.ars-grin. gov/fungaldatabases/. Accessed 18 Aug 2016

Gadgil PD (2005) Fungi on trees and shrubs in New Zealand. Fungi of New Zealand Volume 4. Fungal Diversity, Hong Kong

Gardes MT, Bruns TD (1993) ITS primers with enhanced specificity for basidiomycetes, application to the identification of mycorrhizae and rusts. Mol Ecol 2:113-118

Gilbert GS, Magarey R, Suiter K, Webb CO (2012) Evolutionary tools for phytosanitary risk analysis: phylogenetic signal as a predictor of host range of plant pests and pathogens. Evol Appl 5:869-878. doi:10.1111/j.1752-4571.2012.00265.x

Gilbert GS, Webb CO (2007) Phylogenetic signal in plant pathogen-host range. Proc Natl Acad Sci U S A 104:4979-4983

Gill US, Lee S, Mysore KS (2015) Host versus nonhost resistance: distinct wars with similar arsenals. Phytopathology 105:580-587

Gurtner D, Conedera M, Rigling A, Wunder J (2015) Der Götterbaum dringt in die Wälder nördlich der Alpen vor. Wald Holz 7:22-24

Hajek AE (2004) Natural Enemies - An introduction to biological control. Cambridge University Press, Cambridge. doi:10.5197/j.20440588.2016.033.005

Henricot B, Cook RTA (2008) New report of a powdery mildew on Wisteria in the UK. Plant Pathol 57:374. doi:10.1111/j.13653059.2007.01671.x

Huson DH, Richter DC, Rausch C, Dezulian T, Franz M, Rupp R (2007) Dendroscope - An interactive viewer for large phylogenetic trees. BMC Bioinformatics 8:460 
Kasson MT, O’Neal ES, Davis DD (2015) Expanded host range testing for Verticillium nonalfalfae: potential biocontrol agent against the invasive Ailanthus altissima. Plant Dis 99:823-835

Kasson MT, Short DPG, O’Neal ES, Subbarao KV, Davis DD (2014) Comparative pathogenicity, biocontrol efficacy, and multilocus sequence typing of Verticillium nonalfalfae from the invasive Ailanthus altissima and other hosts. Phytopathology 104:282-292

Katoh K, Misawa K, Kuma K, Miyata T (2002) MAFFT: a novel method for rapid multiple sequence alignment based on fast Fourier transform. Nucleic Acids Res 30:3059-3066

Kirschner R (2010) First record of Erysiphe magnifica on lotus, a host outside the Magnoliales. Mycol Prog 9:417-424

Kirschner R (2011) Observations on Erysiphe platani in Germany. Plant Pathol Quar 1:115-119

Kirschner R (2015) First record of the sexual stage of the powdery mildew Erysiphe pseudolonicerae in Taiwan. Fungal Sci 30:61-66

Kirschner R, Liu WA (2014) Two new hosts of anamorphic Erysiphe quercicola: Cinnamomum camphora and Murraya paniculata. Mycoscience 55:190-195. doi:10.1016/j.myc.2013.08.004

Klenke F, Scholler M (2015) Pflanzenparasitische Kleinpilze. Springer, Berlin

Knüsel S, Conedera M, Rigling A, Fonti P, Wunder J (2015) A tree-ring perspective on the invasion of Ailanthus altissima in protection forests. For Ecol Manag 354:334-343

Kowarik I, Säumel I (2007) Biological flora of Central Europe: Ailanthus altissima (Mill.) Swingle. Perspect Plant Ecol Evol Syst 8:207-237

Kreisel H, Scholler M (1994) Chronology of Phytoparasitic Fungi Introduced to Germany and Adjacent Countries. Bot Acta 107: 387-392

La YJ, Cho S, Shin HD (2013) First report of powdery mildew of Platanus occidentalis caused by Erysiphe platani in Korea. Plant Dis 97:843

Lee HB, Kim CJ, Mun HY, Lee KH (2011) First report of Erysiphe quercicola causing powdery mildew on ubame oak in Korea. Plant Dis 95:77

Lee HB, Lee HW, Mun HY (2013) First report of powdery mildew caused by Erysiphe platani on sycamore (Platanus occidentalis) in South Korea. Plant Dis 97:841

Li CW, Zhang Y, Liu Y, Kang M, Ma XM, Fu LL (2011) First report of powdery mildew caused by Erysiphe euonymi-japonici on Euonymus japonicus in central China. Plant Dis 95:611

Ligoxigakis EK, Markakis EA, Papaioannou IA, Typas MA (2015) First report of powdery mildew of Platanus acerifolia and $P$. occidentalis caused by Erysiphe platani in Greece. Plant Dis 99:286

Limkaisang S, Cunnington JH, Liew KW, Salleh B, Sato Y, Divarangkoon R, Fangfuk W, To-anun C, Takamatsu S (2006) Molecular phylogenetic analyses reveal a close relationship between powdery mildew fungi on some tropical trees and Erysiphe alphitoides, an oak powdery mildew. Mycoscience 47:327-335. doi:10.1007/S10267-006-0311-Y

Limkaisang S, Kom-un S, Furtado EL, Liew KW, Salleh B, Sato Y, Takamatsu S (2005) Molecular phylogenetic and morphological analyses of Oidium heveae, a powdery mildew of rubber tree. Mycoscience 46:220-226. doi:10.1007/S10267-005-0238-8

Lipka U, Fuchs R, Kuhns C, Petutschnig E, Lipka V (2010) Live and let die - Arabidopsis nonhost resistance to powdery mildews. Eur J Cell Biol 89:194-199

Maschek O, Halmschlager E (2016) First report of Verticillium wilt on Ailanthus altissima in Europe caused by Verticillium nonalfalfae. Plant Dis 100:529

Mayor E (1908) Contribution à l'étude des érysiphées de la Suisse. Bull Soc Neuchâtel Sci Nat 35:43-61

Meeboon J, Takamatsu S (2015) Notes on powdery mildews (Erysiphales) in Japan: II. Erysiphe sect. Microsphaera. Mycoscience 56:230-236
Mitchell CE, Power AG (2003) Release of invasive plants from fungal and viral pathogens. Nature 421:625-27

Mougou A, Dutech C, Desprez-Loustau ML (2008) New insights into the identity and origin of the causal agent of oak powdery mildew in Europe. For Path 38:275-287

Pastirčáková K, Pastirčák M, Adamčiková K, Bouznad Z, Kedad A, El Guilli M, Diminić D, Diminić M (2014) Global distribution of Erysiphe platani: new records, teleomorph formation and reexamination of herbarium collections. Cryptog Mycol 35:163-176

Saenz GS, Taylor JW (1999) Phylogeny of the Erysiphales (powdery mildews) inferred from internal transcribed spacer ribosomal DNA sequences. Can J Bot 77:150-168

Schaffner U, Escher R (2012) Grundlagen für die Umsetzung des Zulassungsverfahrens von gebietsfremden Organismen für die klassische biologische Bekämpfung von Schadorganismen in der Schweiz, Schlussbericht. CABI Delémont

Schoch CL, Seifert KA, Huhndorf S, Spouge RV, Levesque CA, Chen W, Fungal Barcoding Consortium (2012) Nuclear ribosomal internal transcribed spacer (ITS) region as a universal DNA barcode marker for fungi. Proc Natl Acad Sci U S A 109:6241-6246. doi:10.1073/pnas. 1117018109

Scholler M, Hemm V, Lutz M (2012) Erysiphe platani: monitoring of an epidemic spread in Germany and molecular characterization based on rDNA sequence data. Andrias 19:263-272

Seko Y, Heluta V, Grigaliunaite B, Takamatsu S (2011) Morphological and molecular characterization of two ITS groups of Erysiphe (Erysiphales) occurring on Syringa and Ligustrum (Oleaceae). Mycoscience 52:174-182

Senn-Irlet BJ, Gross A, Blaser S (2016) SwissFungi: National data- and information center for the fungi of Switzerland (datebase). Version 2. Birmensdorf, Swiss Federal Institute WSL. http://www. swissfungi.ch. Accessed 12 Dec 2016.

Shiroya Y, Nakashima C, Takamatsu S (2008) Erysiphe monascogera sp. nov, an unusual powdery mildew fungus found on fruits of Styrax japonica. Mycoscience 49:199-206

Siahaan SAS, Takamatsu S (2016) Erysiphe aucubae sp. nov, a new powdery mildew species on Aucuba japonica from Japan. Mycoscience 57:251-254

Siegrist M, Holdenrieder O (2016) Die Verticillium-Welke - eine Option zur Bekämpfung des Götterbaumes in der Schweiz? Schweiz Z Forstwes 167:249-257

Sprenger C (1916) Die Freude an der Natur. Mitt Dtsch Dendrol Ges 25: $113-118$

Stamatakis A (2006) RAxML-VI-HPC: maximum likelihood-based phylogenetic analyses with thousands of taxa and mixed models. Bioinformatics 22:2688-2690

Stamatakis A, Hoover P, Rougemont J (2008) A rapid bootstrap algorithm for the RAxML Web servers. Syst Biol 57:758-71

Takamatsu S, Bolay A, Limkaisang S, Kom-un S, To-anun C (2006) Identity of a powdery mildew fungus occurring on Paeonia and its relationship with Erysiphe hypophylla on oak. Mycoscience 47: 367-373

Takamatsu S, Braun U, Limkaisang S, Kom-Un S, Sato Y, Cunnington JH (2007) Phylogeny and taxonomy of the oak powdery mildew Erysiphe alphitoides sensu lato. Mycol Res 111:809-826

Takamatsu S, Hirata T, Sato Y, Nomura Y, Sato Y (1999) Phylogenetic relationships of Microsphaera and Erysiphe section Erysiphe (powdery mildews) inferred from the rDNA ITS sequences. Mycoscience 40:259-268

Takamatsu S, Inagaki M, Niinomi S, Khodaparast SA, Shin HD, Grigaliunaite B, Havrylenko M (2008) Comprehensive molecular phylogenetic analysis and evolution of the genus Phyllactinia (Ascomycota: Erysiphales) and its allied genera. Mycol Res 112: 299-315

Takamatsu S, Ito H, Shiroya Y, Kiss L, Heluta V (2015) First comprehensive phylogenetic analysis of the genus Erysiphe (Erysiphales, 
Erysiphaceae) I. The Microsphaera Lineage Mycologia 107:475489

Takamatsu S, Matsuda S, Grigaliunaite B (2013) Comprehensive phylogenetic analysis of the genus Golovinomyces (Ascomycota: Erysiphales) reveals close evolutionary relationships with its host plants. Mycologia 105:1135-1152. doi:10.3852/13-046

Tanner RA, Pollard K, Varia S, Evans HC, Ellison CA (2015) First release of a fungal classical biocontrol agent against an invasive alien weed in Europe: biology of the rust, Puccinia komarovii var. glanduliferae. Plant Pathol 64:1130-1139
Van Kleunen M, Fischer M (2009) Release from foliar and floral fungal pathogen species does not explain the geographic spread of naturalized North American plants in Europe. J Ecol 97:385-392

Watanabe K, Sato Y (2009) First report of powdery mildew of Madagascar periwinkle caused by Eryisphe sp. in Japan. Plant Pathol 58:95

Weber E (2013) Invasive Pflanzen der Schweiz. Haupt, Bern

White TJ, Bruns T, Lee S, Taylor J (1990) Amplification and direct sequencing of fungal ribosomal RNA genes for phylogenetics. In: Innis MA, Gelfand DH, Sninsky JJ, White TJ (eds.) PCR protocols: a guide to methods and applications. Academic, San Diego, pp 315-322 